\title{
SPRAY IRRIGATION OF LANDFILL LEACHATE: ESTIMATING POTENTIAL EXPOSURES TO WORKERS AND BYSTANDERS USING A MODIFIED AIR BOX MODEL AND GENERALISED SOURCE TERM
}

\author{
Duncan Gray ${ }^{\mathrm{a}}$, Simon J.T. Pollard ${ }^{\mathrm{a}^{*}}$, Lynn Spence ${ }^{\mathrm{b}}$, Richard Smith ${ }^{\mathrm{c}}$ and Jan R. Gronow ${ }^{\mathrm{c}}$ \\ ${ }^{a}$ Integrated Waste Management Centre, Cranfield University, Cranfield, MK43 OAL, UK \\ ${ }^{b}$ Spence Environmental Engineering, 239 Main Street, Pleasanton, CA 94566, USA \\ ${ }^{c}$ Environment Agency, Science Group - Waste and Remediation, Block 1, Government Buildings, Burghill Road, \\ Westbury-on-Trym, Bristol, BS10 6BF, UK
}

\begin{abstract}
Generalised source term data from UK leachates and a probabilistic exposure model (BPRISC 4 ) were used to evaluate key routes of exposure from chemicals of concern during the spraying irrigation of landfill leachate. Risk estimates secured using a modified air box model are reported for a hypothetical worker exposed to selected chemicals within a generalised conceptual exposure model of spray irrigation. Consistent with pesticide spray exposure studies, the key risk driver is dermal exposure to the more toxic components of leachate. Changes in spray droplet diameter $(0.02-0.2 \mathrm{~cm})$ and to spray flow rate (50-1000 1/min) have little influence on dermal exposure, although the lesser routes of aerosol ingestion and inhalation are markedly affected. The risk estimates modelled using this conservative worst case exposure scenario are not of sufficient magnitude to warrant major concerns about chemical risks to workers or bystanders from this practice in the general sense. However, the modelling made use of generic concentration data for only a limited number of potential landfill leachate contaminants, such that individual practices may require assessment on the basis of their own merits.
\end{abstract}

Keywords: spray irrigation, landfill leachate, exposure, aerosols, dermal, risk, assessment

\section{INTRODUCTION}

The irrigation of landfill leachate by spray or pipe flow systems onto grassland, woodland or peat slopes has been widely practised in the UK, particularly in areas (Scotland, Cornwall) where: (i)

\footnotetext{
Corresponding author. Tel: +44 1234754 101; Fax +44 1234751 671; E-mail s.pollard@cranfield.ac.uk
} 
high rainfall leads to the production of large volumes of dilute leachate; (ii) there are appropriate areas of land for irrigation; or (iii) where isolation from sewer watercourses makes off-site disposal difficult or expensive. The practice has been regarded as suitable for dilute, high volume leachate and for the polishing of pre-treated leachate. To be successful, it relies on a combination of physicochemical and biological processes (plant uptake, evapotranspiration, oxidation, nitrification, denitrification, absorption and adsorption) for treating leachate volume and pollutant (chemical oxygen demand (COD), biochemical oxygen demand (BOD), inorganic nitrogen) load (Tyrrel et al., 2002). In Cornwall, for example (Ankers and Ruegg, 1993), leachate concentrations of up to $1500 \mathrm{mg} \mathrm{BOD} 5 / 1$ and $300 \mathrm{mg} \mathrm{NH}_{4}{ }^{+}-\mathrm{N} / \mathrm{l}$, have been spray irrigated to woodland at appropriate loadings that show no detrimental effects on the irrigated vegetation; the loadings having been established on the basis of extended operational experience (Cornwall County Council, 1994). Irrigation equipment used historically includes slotted pipes, rain guns, sprinklers and spray nozzles. The practice was common in the UK during the late 1970s and early 1980s, though fine spray irrigation has decreased in recent years. Currently, most operations are conducted using larger spray guns to redistribute leachate within the landfill site (Figure 1). Application rates per unit area vary substantially (Table 1) but are typically in the order of $c a .50$ $\left(\mathrm{m}^{3} / \mathrm{ha}\right) / \mathrm{d}$ (Knox, 2003; personal communication). Irrigation volumes applied vary widely and seasonally (Table 1) and the practice is regulated through limits on volume and nitrogen load to the receiving land through regulatory conditions on waste management licences.

Spray irrigation results in the generation of aerosols, the volatilisation of contaminants and may result in the subsequent exposure of human receptors (workers, bystanders) to hazardous components in leachate through inhalation, ingestion or dermal exposure routes. Operators of waste facilities have statutory obligations with respect to protecting workers and public health. The general approach for assessing exposures to bystanders from chemical sprays has been to assume that, since bystanders may be exposed less frequently than workers, worker exposure, providing it is found not to be significant, is protective of public health (ACP, 2002).

This study concerns the preliminary screening of potential exposures in hypothetical site workers to specific leachate constituents during the spray irrigation of landfill leachate, with broader public health considerations in mind. We seek to understand the potential significance (in terms of the relative order of magnitude) of exposures that might arise from this practice and the relative contributions to total exposure from a range of exposure routes and hazardous components present in typical UK landfill leachate. In this context, the study might contribute to 
the risk screening requirements for landfill sites recently by the regulator (Environment Agency (2004). Our approach has been to modify and apply a shower model combined with an outdoor air box model (Foster and Chrostowski, 1986; Walden and Spence, 1997) to represent an exposure space, or volume, on site, and to use generalised data from UK leachates as the source term for estimating exposures to hypothetical and maximally exposed workers. The risk estimates and hazard quotients generated cannot be regarded as definitive quantitative predictions of health risk. Their value is in illustrating the dominant exposure routes and likely chemicals of concern and thus in highlighting where further study might best be focused. Following an initial screen, a quantitative examination of the implications of varying certain key parameters in the analysis was undertaken. Results are interpreted in the context of the literature on dermal and inhalation exposures to chemicals in outdoor sprays.

\section{Modelling exposures from spray irrigation}

The estimation of human exposure to chemicals in sprays has its origins in the quantitative models used to estimate exposures to volatile organic compounds (VOCs) in shower stalls and in the development of regulatory models for the control of exposures to pesticide spray (van Hemmen, 1993; Hamey, 2001; USEPA, 2001; European Commission, 2002). The modelling of inhalation exposures to contaminants from water used during showering is reported by several workers (Andelman, 1985; McKone, 1987, 1992; Little 1992a, 1992b). One model, the Integrated Household Exposure Model (IHEM; Foster and Chrostowski, 1986) examines potential household exposures to VOCs through the ingestion of drinking water, inhalation of volatiles while showering, inhalation of water while bathing and through dermal absorption while bathing. An assessment of the IHEM (Carver et al., 1991), notes it as the most conservative of a range of models, predicting shower air concentrations approximately double those of the least conservative model. The IHEM is based on the two-film, gas-liquid mass transfer theory. The rate of volatilisation across the surface of a hypothetical droplet is estimated and the volatile chemical concentration in the air is predicted using the concept of dilution within a box. The model assumes that a volatile organic chemical evaporating into the air of the shower stall (the 'box') is completely mixed and there is no build up of the volatile organic chemical at the airwater interface. It does not take time-dependent distributions or in vivo toxicological considerations following exposure into account. 
Shower models have been adapted to simulate the volatilisation of contaminants during spray irrigation. Walden and Spence (1997) applied the IHEM to a US groundwater irrigation scenario in which potential exposures to BTEX (benzene, toluene, ethylbenzene, xylenes) compounds were a concern. Residential use of contaminated groundwater for watering lawns or gardens (including vegetables) was considered and exposures, including the dermal contact of children playing under the sprinkler with spray, the ingestion of groundwater by the child, and the vapour inhalation by the adult or child under, or downwind of the receptor, were modelled. The model estimates vapour emissions from spray and the aqueous concentrations of contaminants in grounding spray. Air phase concentrations are estimated assuming complete mixing of air in the box and dilution within the box volume. Volatilisation is limited by mass transfer rates.

Briefly, the overall mass transfer coefficient is calculated as (see Glossary, for symbols):

$$
\mathrm{K}_{\mathrm{L}}=\left[1 / \mathrm{k}_{1}+\mathrm{RT} / \mathrm{Hk}_{\mathrm{g}}\right]^{-1}
$$

Gas and liquid phase mass transfer coefficients for contaminants can be estimated from measured values for carbon dioxide $\left(\mathrm{CO}_{2}\right)$ and water $\left(\mathrm{H}_{2} \mathrm{O}\right)$ and the following correlations:

$$
\begin{aligned}
& \mathrm{k}_{\mathrm{g}(\mathrm{VOC})}=\mathrm{k}_{\mathrm{g}(\mathrm{H} 2 \mathrm{O})}\left[18 / \mathrm{MW}_{\mathrm{VOC}}\right]^{0.5} \\
& \mathrm{k}_{1(\mathrm{VOC})}=\mathrm{k}_{\mathrm{l}(\mathrm{CO} 2)}\left[44 / \mathrm{MW}_{\mathrm{VOC}}\right]^{0.5}
\end{aligned}
$$

The overall mass transfer coefficient is adjusted for the shower temperature and the viscosity of water at the lower temperature:

$$
\mathrm{K}_{\mathrm{L}(\mathrm{Ts})}^{\prime}=\mathrm{K}_{\mathrm{L}}\left[\mathrm{T}_{1} \mu_{\mathrm{s}} / \mathrm{T}_{\mathrm{s}} \mu_{1}\right]^{-0.5}
$$

Volatilisation is assumed to be a first order process:

$$
\mathrm{C}_{\mathrm{sh}}=\mathrm{C}_{\mathrm{o}} e^{-\mathrm{K}_{\mathrm{L}}^{\mathrm{t} / 600 \mathrm{~d}}}
$$

The total amount of contaminant that volatilises is given by:

$$
\mathrm{M}_{\mathrm{sh}}=\mathrm{fv} \cdot \mathrm{Q} \cdot \mathrm{time}_{\mathrm{sh}} \cdot \mathrm{C}_{\mathrm{o}}
$$

Finally, the concentration of the shower air can be estimated from:

$$
\mathrm{C}_{\mathrm{sh}}=\mathrm{M}_{\mathrm{sh}} / \mathrm{V}_{\mathrm{sh}}
$$

Walden and Spence (1997) coded the model into the peer-reviewed BPRISC 4 (British Petroleum Risk Integrated Software Cleanup) software program (version 4, BP, 2001). Modelling a spray irrigation scenario, the concentration of volatilised chemicals in the air is calculated using an outdoor box approach, where the 'shower' volume $\left(\mathrm{V}_{\mathrm{sh}}\right)$, the volume of air in which exposure occurs, is represented by a hypothetical box. The dimensions of the box are defined by the product of the wind speed and exposure time, the width of the spray source and the height of the 
receptor. The rate of mass volatilisation is calculated and the air in the box is assumed to be ventilated - differing from the shower scenario, where the air is stagnant and a total volatilised mass is calculated. The model assumes that the air in the box is fully mixed, the concentration in the box is constant and the receptor is inside the box. The model only considers on-site exposures and does not consider receptors at distance from the source. The on-site exposure will be more conservative than any exposures downwind of the source.

\section{METHODOLOGY}

\section{Rationale}

Caution must be exercised in conducting and interpreting quantitative risk studies (HSE, 2003). Conceptual models of exposure and the subsequent characterisation of risks rely on numerous assumptions, many of which have gross incertitude. The value of such analyses is in providing insights into system behaviour, rather than definitive point estimates of risk, for the purpose of informing an appraisal of the options for managing risk (Paustenbach, 2002a). To this end, the aim of this study was to understand the relative importance of a range of exposure routes and trace components in a generalised leachate for worker and bystander exposure during spray irrigation.

\section{Source term data}

Leachate compositional data were abstracted from Robinson (1995), Knox et al., (2000) and Robinson and Knox, (2001) (Table 2). These studies reported analytical data on approximately 4000 leachate samples for 72 landfill sites throughout the UK (Robinson, 1995). Knox et al., (2000), further reported on 57 organic substances and 8 metals listed in the UK Pollution Inventory (PI), in raw and treated leachates from UK landfills. Following extension of the PI in 2002 to include a further 32 substances, these researchers sampled raw leachate and treated effluent from 24 leachate treatment plants. Thirty six substances were tested for and of these 17 were present in more than $5 \%$ of samples (Robinson and Knox, 2001). Our assessment was limited to 17 chemicals (Table 2), selected (i) on the basis that they were identified in $>5 \%$ of the leachates sampled; and (ii) on account of their accepted toxicological relevance and the availability of toxicological data. With respect to chemical classes and multivalent species, for ease, total polynuclear aromatic hydrocarbons $(\Sigma \mathrm{PAH})$ were represented by benzo $[a]$ pyrene 
1 alone, as a conservative surrogate. Similarly, hexavalent chromium $\left(\mathrm{Cr}^{\mathrm{VI}}\right)$ represented the total chromium content of the leachate. Analytical data expressed PCBs in Aroclor 1260 equivalents and the toxicological profile for this substance was used to represent the mixture of PCB compounds. Where dose-response assessment data were not available for each exposure route, route-to-route extrapolations were invoked; oral carcinogenic slope factors and oral reference doses (RfDs) being used for dermal and inhaled exposures for organic compounds. Route extrapolations were not made for inorganics due to reported differences in absorption efficiencies for the two routes of exposure. This is acceptable within BPRISC 4 (BP, 2001) and is supported, for example, by regulatory guidance in the US EPA's Region 9 Preliminary Remediation Goals (EPA, 2003).

\section{Operational assumptions for spray irrigation}

There is considerable scope for variation in flow rates for the irrigation of leachate with the type of irrigation system used and loading rate of the soil, as well as with the age, type and location of the landfill site (Ankers and Ruegg, 1993; Alker et al., 2002). Estimated values for flow rate vary widely from ca. 11 1/min (Alker et al., 2002) to >800 1/min (Webb, 2003; personal communication). A nominal flow rate of $100 \mathrm{l} / \mathrm{min}$ was selected as a reasonable assumption. A review of spray droplet distribution data from Kohl (1974), Edling (1985), Soloman et al., (1985), Li et al., (1994) and Kincaid et al., (1996) and the rationale given by Walden and Spence (1997) resulted in the selection of a value of $0.2 \mathrm{~cm}$ for the droplet diameter. The droplet residence time represents the length of time that a particular droplet is available to contribute emissions of volatile contaminants to the outdoor box. A conservative assumption of droplet residence time is $10 \mathrm{~s}$, to account for volatilisation occurring from water travelling through the air to the point where it is puddled or standing before it soaks into the soil, after which volatilisation is assumed not to occur.

Localised environmental conditions influence exposure. For the probabilistic analysis, triangular distribution data for average wind speed were approximated from the UK annual mean wind speed (BWEA, 2003), values for mean, minimum and maximum being 5, 0 and $9 \mathrm{~m} / \mathrm{s}$, respectively. Finally, because volatilisation increases with temperature and spray irrigation of leachate tends to be carried out during the summer, a leachate temperature of $20^{\circ} \mathrm{C}$ was used. 


\section{Receptor characteristics}

Receptor assumptions are presented in Table 3. A hypothetical maximally exposed receptor is an adult worker occupationally exposed to leachate spray. In this study, receptor assumptions were based, where appropriate, on the Department for the Environment, Food and Rural Affairs' (Defra's) Contaminated Land Exposure Assessment (CLEA) model (Defra, 2002). In CLEA, the critical receptor is a female aged 15 to 69 years. BPRISC 4 default values of fraction of total skin surface area exposed (10\%; hands and forearms) were selected, where the CLEA value is for exposed hands only. The duration of exposure by the potential receptor is highly site-specific, but should reflect a reasonable estimate of the time spent by the receptor in the outdoor box. For consideration of an adult worker on a landfill site during spray irrigation, a conservative estimate of time spent in the outdoor air box is 4 hours, while the maximum would be 8 hours. The number of exposure events per year is based on irrigation during the eight warmest months, for a 5 day working week i.e. 175 days or events/year. BPRISC ${ }_{4}$ default estimates of typical exposure duration for workers is 8.3 years, with a maximum of 50 years (US Bureau of Labor Statistics, 1992). These assumptions were regarded as suitable for the purposes of this screening study.

\section{Modifications to the outdoor air box}

The inhalation of aerosol in spray is a route of potential concern. BPRISC 4 does not code for exposures due to inhalation and ingestion of aerosols (i.e. very fine water droplets) and the model requires modification. Exposure to contaminants that may be dissolved or suspended in the leachate, and then inhaled and inwardly ingested as aerosols was assessed in the same fashion as the ingestion of irrigated groundwater in the BPRISC 4 model. Whilst this approach does not accurately account for aerosols taken directly into the lung airways, it does allow for exposures from larger aerosols trapped in the upper respiratory tract and ingested. A conservative assumption of the percentage of irrigated leachate that would aerosolise was chosen as $1 \% \mathrm{v} / \mathrm{v}$ (Sorber et al., 1976; Camann et al., 1978, 1988). For a 4-hr exposure and a flow rate of 100 $1 / \mathrm{min}$, this gives an estimate of 2401 . The volume of the outdoor air box was estimated to account for the total volume of leachate irrigated. This required selecting a value for the width of the outdoor air box to reflect the diameter of the spray area. Examination of data for irrigation equipment, suggested considerable variation between wetted spray radii of different irrigation systems. Using literature data, conservative estimates of spray diameter (10 m), wind speed (2 $\mathrm{m} / \mathrm{s})$, exposure time $(4 \mathrm{hr})$ and receptor height $(2 \mathrm{~m})$, provide a value for the volume of the 
1 outdoor air box $\left(576,000 \mathrm{~m}^{3}\right)$. Thus the concentration of aerosolised leachate in the air box may

2 be estimated $\left(0.42 \mathrm{ml} / \mathrm{m}^{3}\right)$, assuming instantaneous dispersion and no settling of the aerosol over the exposure time.

\section{Exposure assessment and risk characterisation}

Given an active respiration rate for an adult female receptor of $1.2 \mathrm{~m}^{3} / \mathrm{hr}$, the rate of inhalation of aerosol can then be estimated at $0.52 \mathrm{ml} / \mathrm{hr}$. For a 4-hr exposure time and flow rates of 50 and $1000 \mathrm{l} / \mathrm{min}$, the rates of inhalation of aerosol are 0.26 and $5.2 \mathrm{ml} / \mathrm{hr}$ respectively. Although the model is conservative in that it assumes that aerosols are dispersed and do not settle during exposure, it cannot account for the position of the receptor relative to the source within the outdoor air box, i.e., the closer the receptor the greater the volume of aerosol the receptor is likely to inhale.

A generalised leachate was subjected to probabilistic analysis in $\mathrm{BPRISC}_{4}$ using mean, minimum and maximum leachate compositional data from UK leachates (Table 2). Probability distributions of risk were generated on 10000 iterations of the model using parameter distributions identified in Table 3. BPRISC 4 adopts a US approach to risk estimation and risk characterisation for long term exposures. Chronic average daily doses (CADD; glossary for abbreviations) for non-carcinogens and lifetime average daily doses (LADD) for carcinogens are estimated using (Walden \& Spence, 1997; BP, 2001):

For inhalation

$$
\begin{aligned}
\text { LADD } & =\mathrm{C}_{\text {air }} \cdot I_{n h R} \cdot A A F_{\text {inhal }} \cdot L R F \cdot E T \cdot E F \cdot E D /(365 \cdot L T \cdot B W) \\
C A D D & =C_{\text {air }} \cdot I n h R \cdot A A F_{\text {inhal }} \cdot L R F \cdot E T \cdot E F /(365 \cdot L T \cdot B W)
\end{aligned}
$$

For dermal contact

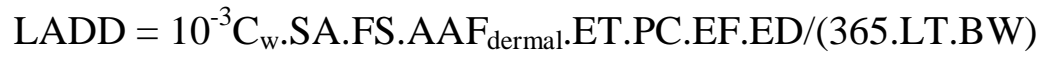

$$
\begin{aligned}
& \mathrm{CADD}=10^{-3} \mathrm{C}_{\mathrm{w}} \cdot \mathrm{SA} \cdot \mathrm{FS} \cdot \mathrm{AAF}_{\mathrm{dermal}} \cdot \mathrm{ET} \cdot \mathrm{PC} \cdot \mathrm{EF} /(365 \cdot \mathrm{LT} \cdot \mathrm{BW})
\end{aligned}
$$

For ingestion

$$
\begin{aligned}
& \mathrm{LADD}=10^{-3} \mathrm{C}_{\mathrm{w}} \cdot \mathrm{IR}_{\mathrm{iw}} \cdot \mathrm{ET} \cdot \mathrm{AAF} \cdot \mathrm{EF} \cdot \mathrm{ED} /(365 \cdot \mathrm{LT} \cdot \mathrm{BW}) \\
& \mathrm{CADD}=10^{-3} \mathrm{C}_{\mathrm{w}} \cdot \mathrm{IR}_{\mathrm{iw}} \cdot \mathrm{ET} \cdot \mathrm{AAF} \cdot \mathrm{EF} /(365 \cdot \mathrm{BW})
\end{aligned}
$$

For carcinogens, risks are estimated as individual excess lifetime cancer risks (IELCR):

$$
\text { IELCR }=\text { SF.LADD }
$$


Potential non-carcinogenic effects are evaluated using the hazard quotient (HQ) and, where relevant, the hazard index $(\mathrm{HI})$ :

$$
\begin{gathered}
\mathrm{HQ}=\mathrm{CADD} / \mathrm{RfD} \\
\mathrm{HI}=\Sigma \mathrm{HQ}_{1}+\mathrm{HQ}_{2}+\mathrm{HQ}_{3} \ldots . \mathrm{HQ}_{\mathrm{n}}
\end{gathered}
$$

The (US) carcinogenic slope factor and hazard quotient approach to risk characterisation above is not adopted in the UK. Occupational and dietary exposures are assessed by reference to occupational exposure limits (OELs), including maximum exposure limits (MELs) for carcinogens, and tolerable daily intakes (TDIs); and are referenced to air concentrations and dose, not risk (Illing, 2001). For pesticide sprays, an acceptable operator exposure level (AOEL - a dose) is used (ACP, 2002). Environmental exposures are conventionally characterised by reference to the drinking water and air quality guidelines (Defra, 2001), that act as risk-based quality standards, expressed as concentrations, in the exposure medium of concern. The above toxicological criteria are referenced to individual statutes and do not easily fit the range of exposures considered in this study. For screening purposes therefore, risks were assessed using the US approach and dose-response data obtained from the USEPA integrated risk information system (IRIS; USEPA, 2003), a database of human health effects that may result from exposure to various substances found in the environment. The updated RISC $_{4}(\mathrm{BP}, 2001)$ software is crossreferenced to IRIS.

\section{RESULTS AND DISCUSSION}

\section{Risk estimates and apportionment}

Risk estimates for the spray irrigation of generalised leachate, with a nominal flow rate of 100 $1 / \mathrm{min}$ and droplet diameter of $0.2 \mathrm{~cm}$, are summarised in Tables 4 to 7 . Taking an IECLR (expressed as a lifetime risk, not an annual) of 1E-04 (1 in ten thousand; LaGrega et al., 2001) as an upper bound guideline for exposure to carcinogens from leachate and, for screening purposes, a HQ value of $1 \mathrm{E}+00$ (i.e. 1) as an indicator level for non-threshold contaminants, we can screen for exposure routes and principal chemicals of concern within the subset of 17 candidates substances (Tables 4 to 7). Acknowledging the uncertainties and model artefacts inherent to such an exercise and discussed below, an examination of the risk estimates modelled using this conservative worst case exposure scenario suggests that they are not of a sufficient order of 
magnitude to warrant major concerns about the chemical risks to workers or bystanders from this practice in a general sense.

In terms of contribution to exposure and reviewing the $95^{\text {th }} \%$ ile values in Tables 4 to 5 , dermal contact with spray and benzo[ $a]$ pyrene emerge as key contributors to the potential carcinogenic risk. Were we to adopt a toxicological equivalency factor (TEF) approach to apportioning the toxicity of $\Sigma \mathrm{PAH}$ between individual PAH the contribution would be lowered significantly. For illustrative purposes, if the risk component attributable to benzo[ $a]$ pyrene is set aside, the potential carcinogenic risk is reduced substantially with the key contributions to dermal exposure from Aroclor 1260, arsenic and dichloromethane (Figure 2 ) at the $95^{\text {th }} \%$ ile level. The HI data by route and by chemical from the Monte Carlo analysis are summarised in Table 6 and 7 , respectively. In terms of overall hazard, the major contributing routes are dermal contact and the inhalation of volatile components from spray irrigated leachate. None of the indices are expressed at a level of significance (i.e. HQ > 1). From Table 7, leachate components with the highest contribution to hazard quotient are Aroclor 1260, arsenic, $\mathrm{Cr}^{\mathrm{VI}}$, lindane, mercury, dichloromethane, naphthalene, toluene and xylenes. Again, because of the toxicity / permeability coefficient of Aroclor 1260 used for all PCBs in the leachate and because the significant route of exposure is by dermal contact, its contribution to the overall hazard is artificially increased.

\section{Sensitivity analysis}

Three simulations were executed varying certain of the input parameters: (i) decreasing the droplet diameter to $0.02 \mathrm{~cm}$, since volatilisation increases with a decrease in droplet size (Edling, 1985); (ii) increasing the flow rate to $1000 \mathrm{l} / \mathrm{min}$; and (iii) decreasing the flow rate to $50 \mathrm{l} / \mathrm{min}$, to reflect the variance in operational practice. An analysis of the carcinogenic risk estimates for each route is shown in Table 8 and for the hazard quotients, in Table 9. Again, dermal contact with irrigated leachate spray drives the exposure under these scenarios that assume that $10 \%$ of the receptor's skin surface area is wetted for $4 \mathrm{hr} / \mathrm{d}$.

Adjusting operational variables such as flow rate, droplet size, droplet residence time and the dimensions of the outdoor air box, appears to exhibit little effect on the level of dermal exposure. This may appear counterintuitive. One normally expects, from Fick's law of diffusion, dermal absorption to be directly proportional to the applied concentration and the amount of chemical applied (entering the box; Paustenbach, 2002b). However, in the spray scenario, dermal exposure is not sensitive to flowrate and droplet size because it assumes that the skin is 
completely wet already and that there is enough water exchange (from the water already in contact with the skin) so that chemicals are not further depleted as they become absorbed. Under these assumptions, the only pathway-specific exposure parameters that dermal exposure to sprayed water pathway is dependent on are skin surface area in contact with water and the time spent in the water. The chemical-specific dermal permeability coefficients are also time dependent. Note this is quite different than the mechanism used for dermal absorption from chemicals in soil. By means of illustration, dermal contact was excluded as a route from the analysis and the effects of operational variables on the other two routes compared with a 'baseline' flow rate of 100 1/min (Figure 4). These data indicate that over a reasonable range of input values, flow rate is an important input variable when estimating exposures via inhalation and ingestion as one would intuitively expect. All values for IECLR via ingestion of leachate aerosol or inhalation are proportionately less for a flow rate of $501 / \mathrm{min}$ compared with a flow rate of $1000 \mathrm{l} / \mathrm{min}$, or reduced droplet size (and a flow rate of $100 \mathrm{l} / \mathrm{min}$ ). Data for the inhalation route are closer for a droplet size of $0.02 \mathrm{~cm}$ compared with a flow rate of $1000 \mathrm{l} / \mathrm{min}$, and greater in comparison to the values for the baseline flow rate of $100 \mathrm{l} / \mathrm{min}$ and droplet size of $0.2 \mathrm{~cm}$, although within the same order of magnitude. The analysis suggests that droplet diameter also plays a significant role in the extent of volatilisation and subsequent exposure for the inhalation of volatile components. Minimum, mean and $95^{\text {th }} \%$ ile values for IECLR are greater for the ingestion of leachate aerosol than corresponding values for the inhalation of volatile contaminants, suggesting that the ingestion route is of greater significance in this scenario. Examination of data for the minimum, mean and $95^{\text {th }} \%$ ile values of HQ (Figure 5) indicate a reversal of this order. Nevertheless, these effects are masked by the apparent dominance of the dermal to the total exposure.

\section{Model artefacts}

As discussed earlier, the width of the outdoor air box is assumed to be constant at $10 \mathrm{~m}$. This is a conservative assumption based on examination of data for $360^{\circ}$ rotating sprinklers, which are subject to very large variations between irrigation systems. The width of the outdoor air box is also treated as if the flow rate was from a single static sprinkler head, rather than from several sprinkler heads spaced along a distribution pipe allowing spray overlap, or from mobile spray irrigation systems. This considerably reduces the size of the outdoor air box and therefore increases the concentration of volatilised contaminants within the box. Thus our assumptions 
about the air box are regarded as conservative. Further, the BPRISC model assumes that the spray (and/or volatile chemicals) is limited to the height of the receptor. All contaminants are assumed to stay below that height and are assumed to pass by the receptor. Therefore, a conservative assumption for height of the box is $2 \mathrm{~m}$ for an adult; this would be reduced for consideration of a child receptor. Use of the surrogate benzo $[a]$ pyrene for $\Sigma \mathrm{PAH}$ and Aroclor 1260 for $\Sigma$ PCB accounts for further artefacts in terms of the magnitude of the risk estimates in this study. This said, the pattern of exposure is consistent with other spray studies within the pesticide spray and exposure literature.

\section{Analogous studies from pesticide spray - bystander risk assessments}

In this study, the dermal contact route is a function of concentration, the dermal permeability coefficient, the fraction of skin exposed and the exposure time, and was shown to be insufficiently sensitive to other variables such as wind speed or flow rate. To confirm, simulations were conducted for each of the following variables in turn: wind speed, water temperature, droplet time, droplet diameter, flow rate and spray width and we found no appreciable difference for $95 \%$ ile risk estimates and only slight differences for the maximum values in two cases (when droplet time changed to 100 seconds; and where flow rate was increased to $10000 \mathrm{l} / \mathrm{min}$ ).

It is useful to consider our findings in light of research on worker and bystander exposure to pesticides, where the dermal and inhalation routes of uptake can also be important (Hamey, 2001; European Commission, 2002; ACP, 2002). Ross et al., (2001) have argued that pesticide toxicology studies have much to offer occupational risk assessments, in particular, with respect to our understanding of dermal exposure. Considering the validity of our modification of Walden and Spence (1997) to account for aerosol inhalation exposure, ACP (2002) reported two experimental studies undertaken by the former Ministry of Agriculture Fisheries and Food (Lloyd and Bell, 1983; Lloyd et al., 1987) on pesticide exposures to bystanders (persons incidentally located at or adjacent to the site of pesticide application who take no action to control exposure) downwind $(8 \mathrm{~m})$ of the spray drift. Harmless tracers were used. From studies of arable crop spray in high wind speeds (Lloyd and Bell, 1983; Lloyd et al., 1987) inhalation exposures of ca. 0.02 $\mathrm{ml} / \mathrm{m}^{3}$ (max. values $0.1 \mathrm{ml} / \mathrm{m}^{3}$ ) and $0.002 \mathrm{ml} / \mathrm{m}^{3}$ were estimated. At a distance of $5 \mathrm{~m}$ from conventional pesticide spray equipment, the typical levels of pesticide spray drift deposited on the ground are reportedly $c a .1 \%$ of the applied dose (ACP, 2002). Using this assumption with 
respect to dermal exposure, Ganzelmeier et al. (1995) estimated bystander exposure to pesticide spray $5 \mathrm{~m}$ from the point of application (at $200 \mathrm{l} / \mathrm{ha}$ ) to be $<0.4 \mathrm{ml} /$ person. These analogous studies reinforce our view that an aerosol exposure estimate of $0.42 \mathrm{ml} / \mathrm{m}^{3}$ is a reasonable worst case estimate.

\section{CONCLUSIONS}

The spray irrigation of landfill leachate is regarded by many operators as an attractive option for meeting discharge consent limits when considered alongside the costs of tankering leachate offsite for specialist treatment. Spray irrigation releases volatiles from the leachate volume and disperses leachate in the form of a fine mist that can be inhaled, ingested or deposited on the skin of site workers. To date, no estimate of these exposures to site workers or bystanders has been conducted. A risk screening exercise in this study used an accepted air box model, with modifications. Chemical exposures to a hypothetical and maximally exposed worker during the simulated spray irrigation of landfill leachate were screened and the IHEM developed to simulate the ingestion of leachate aerosol.

(i) Routes of exposure were ranked in the following order according to their contribution to carcinogenic risk: dermal contact >> ingestion of aerosol > inhalation of volatiles; and, hazard index: dermal contact >> inhalation of volatiles > ingestion of aerosol. Whilst the quantification of site-specific risk estimates from the spray irrigation of leachate may require additional study and was not the purpose of this work, it is prudent for workers to wear suitable personal protective clothing where they are likely to be in close proximity to sprayed leachate, or remain beyond the spray radius.

(ii) Increasing flow rate to $1000 \mathrm{l} / \mathrm{min}$, and to a lesser extent reducing droplet diameter to 0.02 $\mathrm{cm}$ from the 'baseline' parameters of $100 \mathrm{l} / \mathrm{min}$ flow rate and $0.2 \mathrm{~cm}$ droplet size, resulted in increased contribution to both risk and hazard due to inhalation exposure, but had little effect on dermal exposures. Procedures to reduce irrigation flow rate and/or high populations of fine droplets, such as lower operating pressures, larger nozzles, low or downward pointing spray trajectories may serve to reduce potential exposures, by 
minimising volatilisation and spray mist.

(iii) The quantitative risk estimates modelled using this conservative worst case exposure scenario are not of sufficient magnitude to warrant major concerns about chemical risks to workers or bystanders from this practice in the general sense. This would also require occupational exposure limits and environmental assessment levels for these substances to be exceeded in the occupational setting. However, it should also be noted that the modelling made use of generic concentration data for only a limited number of potential landfill leachate contaminants, such that individual practices may require assessment on the basis of their own merits.

(iv) This study adopted a generalised conservative modelling approach. Processes and model features for site-specific application and that, were they better characterised within the model with site data, might lessen the conservative nature of the approach include: (a) the dispersion and aerosol deposition within the outdoor box; (b) a more representative analysis of exposure times; (c) inclusion of various spraying regimes $e . g$. under coppice canopies.

\section{ACKNOWLEDGEMENTS}

This work was funded by the Environment Agency of England and Wales to whom we are grateful for permission to publish. We acknowledge the assistance of Sean Tyrrel, Keith Weatherhead, Frank Taylor and Sam Tothill, Martin Lowe (Cranfield University); Keith Knox (Knox Associates, UK); Sue Webb (CES Group); and Terry Walden (BP International). The opinions and interpretations expressed herein are those of the authors alone. 


\section{GLOSSARY OF TERMS}

\section{Equation 1}

$\mathrm{K}_{\mathrm{L}}=$ overall mass transfer coefficient $(\mathrm{cm} / \mathrm{hr})$

$\mathrm{H}=$ Henry's Law constant for contaminant $\left(\mathrm{atm} \cdot \mathrm{m}^{3} / \mathrm{mol}\right)$

$\mathrm{R}=$ gas constant (assumed to be $\left.8.2 \times 10^{-5}\right)\left(\mathrm{atm} . \mathrm{m}^{3} / \mathrm{mol} . \mathrm{K}\right)$

$\mathrm{T}=$ absolute temperature $(293 \mathrm{~K})$

$\mathrm{k}_{\mathrm{g}}=$ gas phase mass transfer coefficient $(\mathrm{cm} / \mathrm{hr})$

$\mathrm{k}_{1}=$ liquid phase mass transfer coefficient $(\mathrm{cm} / \mathrm{hr})$

\section{Equations 2 and 3}

$\mathrm{k}_{\mathrm{g}(\mathrm{H} 2 \mathrm{O})}=$ gas phase mass transfer coefficient for water $(\mathrm{cm} / \mathrm{hr})=3000 \mathrm{~cm} / \mathrm{hr}$

$\mathrm{k}_{\mathrm{l}(\mathrm{CO} 2)}=$ liquid phase mass transfer coefficient for carbon dioxide $(\mathrm{cm} / \mathrm{hr})=20 \mathrm{~cm} / \mathrm{hr}$

18 = molecular weight of $\mathrm{H}_{2} \mathrm{O}$

44 = molecular weight of $\mathrm{CO}_{2}$

$\mathrm{MW}_{\mathrm{VOC}}=$ molecular weight of contaminant

\section{Equation 4}

$\mathrm{K}_{\mathrm{L}(\mathrm{Ts})}^{\prime}=$ adjusted overall mass transfer coefficient $(\mathrm{cm} / \mathrm{hr})$

$\mathrm{T}_{1}=$ calibration water temperature of $\mathrm{K}_{\mathrm{L}}(\mathrm{K})$

$\mathrm{T}_{\mathrm{S}}=$ shower water temperature $(\mathrm{K})$

$\mu_{1}=$ water viscosity at $T_{1}(\mathrm{~g} / \mathrm{m} . \mathrm{s})$

$\mu_{\mathrm{S}}=$ water viscosity at $\mathrm{T}_{\mathrm{S}}(\mathrm{g} / \mathrm{m} . \mathrm{s})$

\section{Equation 5}

$\mathrm{C}_{\mathrm{sh}}=$ concentration of contaminant in shower droplet after time $\mathrm{t}(\mathrm{mg} / \mathrm{l})$

$\mathrm{C}_{\mathrm{o}}=$ concentration of contaminant in shower water $(\mathrm{mg} / \mathrm{l})$

$\mathrm{d}=$ shower droplet diameter $(\mathrm{cm})$

$\mathrm{t}=$ shower droplet drop time (s)

\section{Equation 6}

$\mathrm{M}_{\mathrm{sh}}=$ mass of contaminant volatilised (mg) 
$1 \mathrm{fv}=$ the fraction of contaminant volatilised $\left(1-e^{-\mathrm{K}_{\mathrm{L}} \mathrm{t} / 600 \mathrm{~d}}\right)(\mathrm{mg} / \mathrm{mg})$

$2 \quad \mathrm{Q}=$ the volumetric flow rate of water $(1 / \mathrm{min})$

3 time $_{\mathrm{sh}}=$ the duration for which the shower water is flowing (min)

$4 \mathrm{Co}=$ the concentration of contaminant in the shower water $(\mathrm{mg} / \mathrm{l})$

\section{$6 \quad$ Equation 7}

$7 \quad \mathrm{C}_{\mathrm{sh}}=$ air concentration in the shower $\left(\mathrm{mg} / \mathrm{m}^{3}\right)$

$8 \quad \mathrm{~V}_{\mathrm{sh}}=$ volume of air in the shower $\left(\mathrm{m}^{3}\right)$.

9

\section{Equations 8-13}

$\mathrm{C}_{\mathrm{air}}=$ concentration of contaminant of concern in air $\left(\mathrm{mg} / \mathrm{m}^{3}\right)$

$\mathrm{C}_{\mathrm{w}}=$ concentration of contaminant of concern in leachate $(\mathrm{mg} / \mathrm{l})$

InhR $=$ inhalation rate $\left(\mathrm{m}^{3} / \mathrm{hr}\right)$

$\mathrm{SA}=$ total skin surface area $\left(\mathrm{cm}^{2}\right)$

$\mathrm{FS}=$ fraction of total skin surface area exposed to irrigation water $\left(\mathrm{cm}^{2} / \mathrm{cm}^{2}\right)$

$\mathrm{IR}_{\mathrm{iw}}=$ water ingestion rate $(\mathrm{ml} / \mathrm{hr})$

$\mathrm{AAF}_{\text {inhal }}=$ contaminant specific absorption adjustment factor for inhalation route (mg/mg);assumed to be 1

$\mathrm{AAF}_{\text {dermal }}=$ contaminant specific absorption adjustment factor for dermal route $(\mathrm{mg} / \mathrm{mg})$

$\mathrm{LRF}=$ lung retention factor (dimensionless); assumed to be 1

$\mathrm{AAF}=$ chemical-specific oral-water absorption adjustment factor $(\mathrm{mg} / \mathrm{mg})$

$\mathrm{ET}=$ exposure time/activity duration (hr/day)

$\mathrm{PC}=$ Chemical specific skin permeability coefficient $(\mathrm{cm} / \mathrm{hr})$

$\mathrm{EF}=$ exposure frequency for occupation (days/year)

$\mathrm{ED}=$ exposure duration (years)

$365=$ days/year

$\mathrm{LT}=$ lifetime (years)

$\mathrm{BW}=$ body weight $(\mathrm{kg})$

\section{Equations 14-15}

IELCR = individual excess lifetime cancer risk for a specified chemical and exposure route (for annual risk this is divided by the exposure duration) 
$1 \quad \mathrm{SF}=$ slope factor (chemical carcinogenic toxicity) for a specified chemical and exposure route

$2{\text { (mg/kg-day })^{-1}}^{-1}$

$3 \quad \mathrm{HQ}=$ hazard quotient for a specific chemical and exposure route

$4 \quad \mathrm{RfD}=$ reference dose for a specific chemical and exposure route $(\mathrm{mg} / \mathrm{kg}$-day)

$5 \quad \mathrm{HI}=$ hazard index

\section{REFERENCES}

Advisory Committee on Pesticides (ACP) (UK) (2002) Bystander risk assessment, Papers for the Open Meeting of $10^{\text {th }}$ July, 2002, Item 4, 9pp. at http://www.pesticides.gov.uk/committees/acp/Open_Meetings/Open_ACP_2002/Bystander3 .pdf $\langle<$ accessed 11-11-03>>

Alker, G. R., Godley, A. R., Hallett, J. E. (2002) Landfill leachate management using short rotation coppice, Final technical report CO5126, WRc Swindon.

Andelman, J.B. (1985) Inhalation exposure in the home to volatile organic contaminants of drinking Water. Sci. Tot. Environ. 47, 443-460.

Ankers, W. B., Ruegg, J. (1993) Research into leachate treatment by woodland and grassplot irrigation. PECD 7/10/135. Waste Regulation Authority, Cornwall County Council, UK

British Petroleum (BP) (2001). Risk integrated software for cleanups RISC 4 , L. Spence and T. Walden (eds.) User's Manual, British Petroleum, London, 439pp.

British Wind Energy Association (BWEA) (2003) UK wind speed database, http://www.bwea.com/noabl/ <<accessed 21 July, 2003〉>

Camann, D.E., Sorber, S.A., Sagik, B.P., Glennon, J.P., Johnson, D.E. (1978) A model for predicting pathogen concentrations in wastewater aerosols. In: Risk assessment and health effects of land application of municipal wastewater and sludges, University of Texas at San Antonio, Texas, US, pp 240-267

Camann, D.E., Moore, B.E., Harding, H.J., Sorber, C.A. (1988) Microorganism levels in air near spray irrigation of municipal wastewater: the Lubbock infection surveillance study. J. Water Pollut. Control Fed. 60, 1960-1970.

Carver, J.H., Seigneur, C.S., Block, R.M., Miller, T.M. (1991) Comparison of exposure models for volatile organics in tap water. In: Proceedings of Hazmacon, Santa Clara, California, US 
Cornwall County Council (1994) A manual of good practice for leachate treatment by irrigation to land - summary report, Cornwall County Council Waste Regulation Authority for the Department of the Environment, 54pp.

Department for Environment, Food and Rural Affairs (Defra) (UK) (2001). Air quality strategy: particles, benzene, carbon monoxide and polycyclic aromatic hydrocarbons; Section 4: polycyclic aromatic hydrocarbons. http://www.defra.gov.uk/environment/consult/airqual01/11.htm

Department for Environment, Food and Rural Affairs (Defra) and the Environment Agency (2002) Contaminants in soil: collation of toxicological data and intake values for humans. Environment Agency, Bristol, http://www.defra.gov.uk/environment/landliability/pdf/clr9.pdf

Edling, R.J. (1985) Kinetic energy, evaporation and wind drift of droplets from low pressure irrigation nozzles. Trans Amer. Soc. Agric. Eng. 28, 1543-1550.

Environment Agency (2004) Guidance on assessment of risks from landfill sites, External consultation v1.0, May 2004, Environment Agency, Bristol, 73pp.

European Commission (2002). Guidance document on dermal absorption. EC Health and Consumer Protection Directorate-General, Sanco/222/2000 rev.6, dated $27^{\text {th }}$ November 2002, 14pp.

Foster, S.A., Chrostowski, P.C (1986) Integrated household exposure model for use of tap water contaminated with volatile organic chemicals. Presented at the $79^{\text {th }}$ Annual Meeting of the Air Pollution Control Association, Minneapolis, Minnesota, pp 1-25.

Ganzelmeier, H., Rautmann, D., Spangenberg, R., Streloke, M., Herrmann, M., Wenzelbuger, HJ. and Walter, H-F. (1995) Studies on the spray drift of plant protection products. Results of a test programme carried out through the Federal Republic of Germany. Mitteilungen aus de Biologischen Bundesansalt für Land- und Forstwirtschaft, Berlin-Dahlem, Heft 305.

Giardino, N.J., Esmen, N.A., Andelman, J.B. (1992) Modelling volatilisation of trichloroethylene from a domestic shower spray: the role of drop-size distribution. Environ Sci Technol, 26, 1602-1606.

Hamey, P.Y. (2001) An example to illustrate the potential use of probabilistic modelling to estimate operator exposure to pesticides. Ann Occup. Hyg. 45(1001) S55-S64.

HSE (2003) Good practice and pitfalls in risk assessment, HSE Books, Sudbury, 54pp. 
Kincaid, D.C., Solomon, K.H., Oliphant, J.C. (1996) Drop size distributions for irrigation sprinklers. Trans Amer. Soc. Agric. Eng. 39, 839-845.

Kohl, R. A. (1974) Drop size distribution from medium-sized agricultural sprinklers. Trans Amer. Soc. Agric. Eng. 17, 690-693.

Kohl, R. A., DeBoer, D.W. (1984) Drop size distributions for a low pressure spray type agricultural sprinkler. Trans Amer. Soc. Agric. Eng. 27, 1836-1840.

Knox, K., Robinson, H.D., van Santen, A., Tempany, P.R. (2000). The occurrence of trace organic components in landfill leachates and their removal during on-site treatment. IWM Sci. Tech. Rev. 11, 5-10.

LaGrega, M.D., Buckingham, P.L. and Evans, J.C. (2001) Hazardous waste management, $2^{\text {nd }}$ edition, McGraw-Hill International Edition, pp.300-301

Li, J., Kawano, H., Yu, K. (1994) Droplet size distributions from different shaped sprinkler nozzles. Trans Amer. Soc. Agric. Eng. 37, 1871-1878.

Little, J.C. (1992a) Applying the two-resistance theory to contaminant volatilisation in showers. Environ. Sci. Technol. 26, 1341-1349.

Little, J.C. (1992b) Correspondence: Comment on Human exposure to volatile organic compounds in household tap water: the indoor inhalation pathway. Environ. Sci. Technol. 26, 836-837.

Lloyd G.A. and Bell, G.J. (1983) Hydraulic nozzles: a comparative study. Ministry of Agriculture Fisheries and Food, London, UK

Lloyd G.A., Bell, G.J., Samuels, S.W., Cross, J.V., and Berries, A.M. (1987) Orchard sprayers: comparative operator exposure and spray drift study. Ministry of Agriculture Fisheries and Food, London, UK

Illing, P. (2001) Toxicity and risk: context, principles and practice. Taylor and Francis, London, $154 \mathrm{pp}$.

McKone, T.E. (1987) Human Exposure to volatile organic compounds in household tap water: the indoor inhalation pathway. Environ. Sci. Technol. 21, 1194-1201.

McKone, T.E. (1992) Correspondence: Comment on Human exposure to volatile organic compounds in household tap water: the indoor inhalation pathway. Environ. Sci. Technol., 837-838. 
Paustenbach, D.J. (2002a) Primer on human and environmental risk assessment. In: Human and ecological risk assessment: theory and practice (D.J Pautenbach, ed.), John Wiley \& Sons, New York, NY, 45-46

Paustenbach, D.J. (2002b) Exposure assessment. In: Human and ecological risk assessment: theory and practice (D.J Pautenbach, ed.), John Wiley \& Sons, New York, NY, 215-216

Robinson, H.D. (1995) A review of the composition of leachates from domestic wastes in landfill sites. R\&D Technical Report CWM072/95, Environment Agency, Bristol, UK

Robinson, H.D, Knox, K. (2001) Updating the landfill leachate Pollution Inventory reporting tool. R\&D Technical Report No PI-496/TR(2), Environment Agency, Bristol, UK

Ross, J.H., Driver, J.H., Cochran, R.C., Thongsinthusak, T. and Krieger, R.I. (2001) Could pesticide toxicology studies be more relevant to occupational risk assessment?. Ann Occ. Hyg. 54(1001): S5-S17

Solomon, K.H., Kincaid, D.C., Bezdek, J.C. (1985) Drop size distributions for irrigation spray nozzles. Trans Amer. Soc. Agric. Eng. 28, 1966-1974.

Sorber, C.A., Bausum, H.T., Schaub, S.A., Small, M.J. (1976) A study of bacterial aerosols at a wastewater irrigation site. J. Water Pollut. Control Fed. 48, 2367-2379.

Tyrrel, S.F., Leeds-Harrison, P.B., and Harrison, K.S. (2002) Removal of ammoniacal nitrogen from landfill leachate by irrigation onto vegetated treatment planes. Wat. Res. 36, 291-299.

US Bureau of Labor Statistics (1992) http://www.bls.gov/

USEPA (2001). Risk assessment guidance for Superfund. Volume 1: Human health evaluation manual. Part E, supplementary guidance for dermal risk assessment (interim). Review draft for public comment. EPA/540/R/99/05, Office of solid waste and emergency response 9285.7-02EP, USEPA. 2001. Washington, DC

USEPA (2003). Region 9: Superfund. Preliminary remediation goals, http://www.epa.gov/region09/waste/sfund/prg/index.htm

USEPA (2003). Integrated risk information system. Current update, 2003. available at http://www.epa.gov/iris/subst/index.html $<<$ accessed 11/11/03〉>

Walden, J.T., Spence, L.R. (1997) Risk-based BTEX screening criteria for a groundwater irrigation scenario. Hum. Ecol. Risk Assess. 3, 699-722. 
1 Table 1. Illustrative spray irrigation conditions for UK landfill sites in Cornwall, UK

2

\begin{tabular}{|c|c|c|c|c|c|}
\hline Site & $\begin{array}{l}\text { Pump rates } \\
\left(\mathrm{m}^{3} / \mathrm{hr}\right)\end{array}$ & $\begin{array}{l}\text { Spray regime } \\
\text { (vols. in 2002) }\end{array}$ & $\begin{array}{l}\text { Nitrogen load } \\
\text { (kg/ha) }\end{array}$ & Leachate quality & Conditions \\
\hline $\mathrm{A}$ & $\begin{array}{l}80 \text { (wood); } 50 \\
\text { (fields) }\end{array}$ & $\begin{array}{l}150055 \mathrm{~m}^{3} \\
32500 \mathrm{~m}^{3} \text { (Nov.); } \\
389 \mathrm{~m}^{3} \text { (Sept.) }\end{array}$ & $\begin{array}{l}50 \text { (grassland) } 70 \\
\text { (wood) }\end{array}$ & $\begin{array}{l}35-45 \mathrm{mg} / \mathrm{l} \mathrm{NH}_{4}{ }^{-}-\mathrm{N} \\
5-16 \mathrm{mg} / \mathrm{NO}_{3}^{-}-\mathrm{N}\end{array}$ & $\begin{array}{l}\text { Old leachate; } \\
\text { Hypro }^{\mathrm{TM}_{\text {Spray }}} \\
\text { nozzle } 10 \mathrm{~mm}\end{array}$ \\
\hline B & $\begin{array}{l}80 \text { (wood); } 50 \\
\text { (fields) }\end{array}$ & $\begin{array}{l}23600 \mathrm{~m}^{3} \\
7600 \mathrm{~m}^{3} \text { (Nov.); } \\
725 \mathrm{~m}^{3} \text { (Sept.) }\end{array}$ & $\begin{array}{l}700 \text { (wood); } 500 \\
\text { (grassland) }\end{array}$ & $\begin{array}{l}9 \mathrm{mg} / \mathrm{l} \mathrm{NH}_{4}^{+}-\mathrm{N} \\
20 \mathrm{mg} / \mathrm{NO}_{3}^{-}-\mathrm{N}\end{array}$ & $\begin{array}{l}\text { Weak leachate } \\
\text { only; Hypro } \\
\text { spray nozzle } 10 \\
\text { mm }\end{array}$ \\
\hline $\mathrm{C}$ & $\begin{array}{l}80 \text { (wood); } 50 \\
\text { (fields) }\end{array}$ & $\begin{array}{l}6060 \mathrm{~m}^{3} \\
859 \mathrm{~m}^{3} \text { (Nov.); } \\
229 \mathrm{~m}^{3} \text { (Sept.) }\end{array}$ & $\begin{array}{l}700 \text { (wood); } 500 \\
\text { (grassland) }\end{array}$ & $\begin{array}{l}220 \mathrm{mg} / \mathrm{l} \mathrm{NH}_{4}^{+}-\mathrm{N} \\
7 \mathrm{mg} / \mathrm{NO}_{3}^{-}-\mathrm{N}\end{array}$ & $\begin{array}{l}\text { Hypro }^{\mathrm{TM}} \text { spray } \\
\text { nozzle } 10 \mathrm{~mm}\end{array}$ \\
\hline
\end{tabular}

Table 2. Leachate compositional data (after Robinson, 1995; Knox et al., 2000; and, Robinson and Knox, 2001).

\begin{tabular}{|c|c|c|c|c|c|}
\hline Chemical & $\begin{array}{c}\text { Frequency of } \\
\text { occurrence in } \\
\text { leachate samples }(\%)\end{array}$ & $\begin{array}{c}\text { Assumed } \\
\text { distribution }\end{array}$ & $\begin{array}{l}\text { Mean } \\
(\mathrm{mg} / \mathrm{l})\end{array}$ & $\begin{array}{c}\text { Min } \\
(\mathrm{mg} / \mathrm{l})\end{array}$ & $\begin{array}{c}\operatorname{Max} \\
(\mathrm{mg} / \mathrm{l})\end{array}$ \\
\hline aniline & 17 & Triangular & $1.46 \mathrm{E}-03$ & $1.00 \mathrm{E}-03$ & $7.00 \mathrm{E}-03$ \\
\hline Aroclor 1260 & 20 & Triangular & $8.00 \mathrm{E}-05$ & $2.00 \mathrm{E}-05$ & $3.40 \mathrm{E}-04$ \\
\hline arsenic & 94 & Triangular & $1.60 \mathrm{E}-02$ & $1.0 \mathrm{E}-03$ & $1.60 \mathrm{E}-01$ \\
\hline benzo $[a]$ pyrene & 29 & Triangular & $5.60 \mathrm{E}-03$ & $5.25 \mathrm{E}-03$ & $1.22 \mathrm{E}-02$ \\
\hline cadmium & 20 & Triangular & $2.00 \mathrm{E}-02$ & $1.00 \mathrm{E}-02$ & $3.00 \mathrm{E}-02$ \\
\hline chromium (VI) & 33 & Triangular & $9.20 \mathrm{E}-02$ & $5.00 \mathrm{E}-02$ & $1.24 \mathrm{E}+00$ \\
\hline dieldrin & 7 & Triangular & $1.30 \mathrm{E}-04$ & $7.00 \mathrm{E}-05$ & $2.00 \mathrm{E}-04$ \\
\hline ethylbenzene & 15 & Triangular & $1.90 \mathrm{E}-02$ & $1.00 \mathrm{E}-02$ & $5.90 \mathrm{E}-02$ \\
\hline hexachlorobenzene & 17 & Triangular & $9.00 \mathrm{E}-05$ & $4.00 \mathrm{E}-05$ & $2.20 \mathrm{E}-04$ \\
\hline lead & 8 & Triangular & $6.00 \mathrm{E}-02$ & $5.00 \mathrm{E}-02$ & 4.10E-01 \\
\hline lindane & 23 & Triangular & $3.37 \mathrm{E}-03$ & $2.00 \mathrm{E}-05$ & $2.03 \mathrm{E}-02$ \\
\hline mercury & 30 & Triangular & $3.00 \mathrm{E}-04$ & $1.00 \mathrm{E}-04$ & $1.00 \mathrm{E}-03$ \\
\hline dichloromethane $^{1}$ & 13 & Triangular & $4.28 \mathrm{E}-02$ & $1.00 \mathrm{E}-03$ & $5.04 \mathrm{E}-01$ \\
\hline naphthalene & 70 & Triangular & $3.04 \mathrm{E}-03$ & $1.00 \mathrm{E}-04$ & $4.20 \mathrm{E}-02$ \\
\hline toluene & 54 & Triangular & $8.70 \mathrm{E}-02$ & $1.00 \mathrm{E}-02$ & $1.29 \mathrm{E}+00$ \\
\hline 1,2,3-trichlorobenzene & 17 & Triangular & $5.80 \mathrm{E}-04$ & $8.00 \mathrm{E}-05$ & $1.29 \mathrm{E}-03$ \\
\hline xylenes & 35 & Triangular & $5.90 \mathrm{E}-02$ & $3.00 \mathrm{E}-02$ & $2.08 \mathrm{E}-01$ \\
\hline
\end{tabular}

${ }^{1}$ methylene chloride 
1 Table 3. Summary of baseline input parameters for BPRISC 4.

\begin{tabular}{|c|c|c|c|c|c|}
\hline Input Parameter & Distribution & Mean & Std Dev & Min & Max \\
\hline \multicolumn{6}{|l|}{ Receptor characteristics } \\
\hline body weight $(\mathrm{kg})^{\mathrm{a}}$ & Normal & 68.5 & 13.9 & 46.4 & 68.5 \\
\hline lifetime (y) & Constant & 70 & - & - & - \\
\hline ingestion rate $(\mathrm{ml} / \mathrm{hr})$ & Constant & $5.2 \mathrm{E}-01$ & - & - & - \\
\hline inhalation rate outdoors $\left(\mathrm{m}^{3} / \mathrm{hr}\right)^{\mathrm{c}}$ & Triangular & 1.23 & - & 4.11 & 1.63 \\
\hline lung retention factor (unitless) & Constant & 1 & - & - & - \\
\hline total skin surface area $\left(\mathrm{cm}^{2}\right)$ & Constant & $1.76 \mathrm{E}+04$ & - & - & - \\
\hline fraction skin exposed to water (unitless) & Constant & $1.1 \mathrm{E}-01$ & & & \\
\hline height of breathing zone (m) & Constant & 2 & - & - & - \\
\hline \multicolumn{6}{|l|}{ Exposure characteristics } \\
\hline time in sprinkler (hr/day) & Constant & 4 & - & - & - \\
\hline exp. freq irrigation (events/year) & Constant & 175 & - & - & - \\
\hline exposure duration leachate $(\text { years })^{\mathrm{d}}$ & Lognormal & 8.3 & 8.7 & 0 & 50 \\
\hline \multicolumn{6}{|l|}{ Spray operational parameters } \\
\hline width of sprinkler spray $(\mathrm{m})$ & Constant & 10 & - & - & - \\
\hline sprinkler flow rate $(1 / \mathrm{min})$ & Constant & 100 & - & - & - \\
\hline droplet diameter sprinkler $(\mathrm{cm})$ & Constant & 0.2 & - & - & - \\
\hline droplet droptime for sprinkler (s) & Constant & 10 & - & - & - \\
\hline \multicolumn{6}{|l|}{ Environmental parameters } \\
\hline temperature of irrigation water $\left({ }^{\circ} \mathrm{C}\right)$ & Constant & 20 & - & - & - \\
\hline average windspeed $(\mathrm{m} / \mathrm{s})^{\mathrm{b}}$ & Triangular & 5 & - & 0 & 9 \\
\hline
\end{tabular}

${ }^{\text {a }}$ body weight maximum and minimum values taken as $5^{\text {th }}$ and $50^{\text {th }}$ percentile values for critical adult female receptor aged 1659 (Defra, 2002)

baverage wind speed approximated from BWEA (2003)

cinhalation rate determined: mean of active respiration rate; minimum of passive respiration rate; and, maximum as $95^{\text {th }}$ percentile of active respiration rate for critical adult female receptor aged 16-59 (CLEA, 2003)

dexposure duration; default values from BPRISC, based upon Bureau of Labor Statistics (1992). 




Fig. 1. Representative spray irrigation of landfill leachate using spray guns and illustrating typical spray radii 